\title{
Optimal resources to reduce the unmet surgical needs in low-resource settings
}

\author{
Taiwo A. Lawal ${ }^{1,2^{*}}$ (D) on behalf of the Global Initiatives for Children's Surgery
}

Keywords: Children's surgery, Global surgery, Resources, Unmet surgical needs

To the Editor:

The Global Initiative for Children's Surgery, a consortium of providers and experts recently produced, through consensus, a document on Optimal Resources for Children's Surgery (OReCS) [1]. Hitherto, there has not been consensus on resources required to equip surgical facilities for children in low-resource settings in spite of the magnitude of unmet surgical needs [1].

Resolution A68/15 of the World Health Assembly [2], which was based on findings from the Lancet Commission on Global Surgery [3] and others, involves strengthening emergency and essential surgical care and anesthesia but did not emphasize the role of children's surgical care in achieving universal health coverage (UHC). Children have different perioperative concerns from adults, hence requiring special considerations if the goals of UHC are to be attained and safe surgery ensured. Children are vulnerable and often lack access to surgical care [1, 3, 4]; this is most evident in South Asia and sub-Saharan Africa where as much as $95 \%$ lack access to surgical care [4].

The OReCS publication highlights the benefits of safe surgery in children and facilities available for surgical care and provides template for functioning and equipment required for levels of basic, intermediate, and complex/advanced care [1]. Healthcare facilities were designated according to the specification of care expected, the range of procedures to be performed, and the surgical instruments and equipment available to safely perform the operations.

Optimal resources required for the surgical care of children include trained human resources for health; skills in clinical care, surgery, nursing, and anesthesia; physical infrastructures and equipment; and supplies [1]. Provision of resources based on designation of level of care each facility, responsibilities, and clinical capabilities; provision of anesthesia for different age groups and complexities of conditions; and institution of mechanisms for quality assurance will be a good step in improving access to care. It also provides an opportunity for incorporation of children's surgical care into National Surgical, Obstetric and Anesthesia Plans, in low-resource settings.

\section{Abbreviations}

GICS: Global Initiatives for Children's Surgery; OReCS: Optimal Resources for Children's Surgery; UHC: Universal Health Coverage

\section{Acknowledgements}

The Global Initiatives for Children's Surgery is acknowledged for the support.

\section{Author's contributions}

TAL is the sole author of this manuscript. The author read and approved the final manuscript.

\section{Author's information \\ TAL is a pediatric surgeon working at a university teaching hospital in sub- Saharan Africa.}

\section{Funding}

No funding was received for this letter to the editor.

\section{Availability of data and materials}

Not applicable.

Ethics approval and consent to participate Not applicable.

\section{Consent for publication} Not applicable.

Correspondence: taiwo.lawal@hotmail.com
${ }^{1}$ Division of Pediatric Surgery, Department of Surgery, University of Ibadan and University College Hospital, Ibadan, Nigeria

${ }^{2}$ Department of Surgery, College of Medicine, University of Ibadan, PMB 5017, Ibadan 200212, Nigeria

Competing interests

The author declares that he has no competing interests. 
Received: 24 September 2019 Accepted: 23 October 2019

Published online: 27 November 2019

\section{References}

1. GICS Collaborators. Optimal resources for children's surgical care: executive summary. World J Surg. 2019;43:978-80.

2. Strengthening emergency and essential surgical care and anaesthesia as a component of universal health coverage. Geneva: 68th World Health

Assembly, 2015. Available at: http://apps.who.int/gb/ebwha/pdf_files/WHA6 8/A68_R15-en.pdf. Accessed April 22, 2019.

3. Meara JG, Leather AJ, Hagander L, et al. Global Surgery 2030: evidence and solutions for achieving health, welfare, and economic development. Lancet. 2015;386:569-624.

4. Alkire BC, Raykar NP, Shrime MG, et al. Global access to surgical care: a modelling study. Lancet Glob Health. 2015;3:e316-23.

\section{Publisher's Note}

Springer Nature remains neutral with regard to jurisdictional claims in published maps and institutional affiliations.

\section{Submit your manuscript to a SpringerOpen ${ }^{\circ}$ journal and benefit from:}

- Convenient online submission

- Rigorous peer review

- Open access: articles freely available online

High visibility within the field

- Retaining the copyright to your article

Submit your next manuscript at $\boldsymbol{\nabla}$ springeropen.com 